\title{
The Health Education Process of Hospital Visitors through the Educative Brochure
}

\author{
H. M. Tamsir Ridho
}

Fakultas Ilmu Komunikasi Universitas Mercu Buana, West Jakarta, Indonesia

\begin{abstract}
The presence of a hospital does not only treat patient. However, they also educate the public. Hospitals should be aware of their responsibility to educate the public, for insistence, educating by using brochures. Related to this matter, the researcher was interested in conducting research related to the Health Education Process for Hospital Visitors through the Educative Brochure. This research used the theoretical foundation of Public Relations communication media and the use of media in Public Relations activities at Maria Assumpta Rumanti's book, the Basics of Public Relations. This research used a qualitative approach with a descriptive qualitative research. The research method was a case study by conducting in-depth interview with the participants.
\end{abstract}

Keywords-Brochure management, Health Media Information, Hospital.

\section{INTRODUCTION}

The competitive business of health services is increasingly tight. This encourages each hospital to further improve its health services and to innovate more with health service programs that can meet the needs of public, namely patients. Nowadays, hospital does not only observe the quality of their health services but also the public image and the public trust toward the hospital.

The existence of a hospital does not only treat for patients. However, they must be able to educate the public about how to maintain their health. To convey health information, especially for the hospital visitors, they need appropriate and supported media so that the visitors can understand very well. There are 2 types of media with different objectives, such as information media and educative media. Media information is media in which the writing material increases knowledge for the readers (http://hospitals.webometrics.info).

Information media contains material that can meet the public information needs. Meanwhile, educative media refers to media whose material introduces the reader about new ways to carry out an activity or to solve a problem (Effendy, 2003: 31). Siloam Hospitals Lippo Village strives to convey information well to the public as an effort to give more attention for the visitors. Siloam Hospitals Lippo Village in utilizing its communication media for external parties, the company also paid attention to the publication of the media.

The media which is published by Siloam Hospitals Lippo Village observes the media goals as an informative and educative media. Educating in this case refers to providing new knowledge or add insight for the public.
The purpose of the publication of the Siloam Hospitals Lippo Village media organization is also to build a good image in the public/visitors eyes. Siloam Hospitals Lippo Village publishes one of its communication media, namely brochure media that aims to broaden the horizons of visitors who are visiting Siloam Hospitals Lippo Village.

Through this brochure, it is expected to educate and explain the many dangerous diseases that infect the body and how to wash hands properly to prevent dangerous diseases. This can educate hospital visitors to always wash their hands after having the activities and visiting the patients in the hospital. The researcher was interested in exploring the media brochure published by this hospital to provide health information on how to maintain good health and to increase the visitor knowledge. This media brochure is also used indirectly to educate visitors on how to maintain a healthy body and to increase the Siloam Hospitals Lippo Village information. The brochure of this hospital is not directly intended to promote a service or facility provided by this hospital. However, the brochure aims to increase visitor knowledge about ways to prevent diseases in the human body easily. Hence, several goals which was set by Siloam Hospitals Lippo Village is to pay more attention and educate the public very well.

Brochure generally functions as an informative media. As the informative media, the brochure aims to convey information so that the public can increase their knowledge and insight (Iriantara \& Surachman, 2006: 162). The Siloam Hospitals Lippo Village educative brochure produced by the Business Development division 
aims to increase visitor knowledge about health infections and their prevention.

The brochure media used by Siloam Hospitals Lippo Village is intended to educate visitors about health information which does not only to promote a service or doctor at this hospital. To maximize the information delivery through the brochure on health education, it requires a consistent production of brochures on a regular basis so that visitors can be more aware of ways to prevent diseases affecting the body. The researchers is also interested in exploring the consistency of educative brochure production by Siloam Hospitals Lippo Village, which, in this case, is one of the media used by hospitals to provide health education for the visitors. The establishment of Siloam Hospital Lippo Village educative brochure is a form of hospital care in providing health care for the visitors in order that the visitors will be inspired to get the health service in this hospitals as they care of their public health. Hence, the researcher is interested in exploring how Siloam Hospitals Lippo Village uses educative brochures to educate the public, especially visitors. Based on these descriptions, the researcher is interested in further researching the Health Education Process of Hospital Visitors through the Educative Brochure.

Based on these explanations, the researcher is interested in discussing and focusing this research on the Health Education Process of Hospital Visitors through the Educative Brochure. By this research, the researcher wanted to understand and then explain how the Health Education Process of Hospital Visitors Through the Educative Brochures. The results of this study are expected to be a reference frame for Siloam Hospitals Lippo Village in managing brochures as a media information brochure for the public as well as continuing. Thus, this research can be used as a source of data to perfect the media and meet the public information needs, especially for health education.

\section{LITERATURE REVIEW}

\section{Public Relations}

Rex Harlow explains that Public Relations is a management function that is distinctive and supports coaching, maintaining a common path between an organization and its community, concerning communication activities, understanding, acceptance and cooperation; involving the management in dealing with problems, helping the management to face public opinion; supporting management in following and utilizing change effectively; acting as an early warning system in anticipating trends on the use of research, and communication techniques, such as good and ethical communication as a primary means (Yuliawati \& Irawan, 2016: 211).

Public relations as a management and communication discipline needs to understand that they are strongly influenced by information and communication technology, especially in the last decade. At present, Public Relations cannot avoid dealing with the digital media, social media, and cell phones. These media are part of the works that will become one of the drivers of new work within the scope of Pulic Relations work. (Vercic et al. 2014: 1).

To achieve the promotion objectives, the communication strategies of the promotors are facilitated by the existence of social media in communication activities. Social media can function as a network agent and a window for criticism and suggestions. (Rowe and Pitfield, 2018). The implementation of social media promotion can be beneficial for the company, such as, first, it can reach more people in a shorter time. Thus, many consumers can be reached because of extensive social media penetration. Thus, they could receive information about the product company (new). Second, the spread of positive words through social networks can influence the decision making of potential customers and might increase their purchase intentions. (Baum et al. 2018: 1)

Company Monitor: This function makes company policies and programs match the expectations of the public. The enthusiasm of entrepreneurs must encompass the work of Public Relations practitioners. In addition, this is perhaps the most powerful reason for senior Public Relations officials to report to the top management (Wilcox, Ault \& Agee, 2006: 24).

\section{Public Realtions Campaign and Environmental Communication}

Public Relations (PR campaign) according to Ruslan (2012) in the narrow sense aims to increase the awareness and knowledge of the target readers to grab attention and foster positive perceptions or opinions on an organization or organization's activities (corporate activities) In order to create a public trust and good image through the intensive delivery of information within a certain period of time. In a more general or broad sense, the Public Relations campaign provides continuous illumination and understanding which motivates the public towards a particular activity or program through continuous and planned communication processes and techniques to achieve publicity and a positive image. (Libertine, 2014)

Environmental communication according to (Robert Cox, 2010) is a pragmatic and constructive media to provide the public knowledge about the environment. 
Concerning the message packaging strategy in the media to foster public awareness and participation in environmental management, the main communicators in environmental communication are government and nongovernment organizations that have a commitment of environmental management (Yuliawati, 2019: 82).

The Environmental communication analyzed in this research was related to hydroponic growing activities. This was motivated by the limited available land in the urban housing complexes. The community's knowledge has yet to be popularized about the optimization of the benefits of mining despite its limited extent. The Limited information about hydroponics that does not only functions to make use of the narrow but also at the same time, it can also improve the nutrition and family welfare. Planting without soil means changing the way the needs of plants are supplied by irrigation, but this does not mean the needs of plants can be eliminated or reduced. The same is true for plants with light and temperature. Plants need light, temperature, and humidity in accordance with the original. This needs to be carved out considering that the plant will not grow well without the light and temperature according to its needs (Yuliawati, 2018: 152).

Public Relations Media in communication is a means of connecting used by a Public Relations practitioner with the public, namely internal and external to help the goal (Rumanti, 2005: 118). The communication media used by Public Relations is divided into 2 types of media, namely internal communication media and external communication media. The internal media in an organization or company can be in the form of magazines, tabloids, newsletters, company websites, company intranets, and many other types, while the external media is created by printed and electronic media such as brochures, leaflets, annual reports, company profiles, social media companies that are devoted to the interests of relations with external companies.

\section{Brochure}

According to the Indonesian Dictionary by JS. Badudu (2010), Brochure is a short publication consisting of several pages without volumes. In addition, the brochure is also interpreted as printed leaflets containing brief information about companies, organizations for public knowledge (Iriantara \& Surachman, 2006: 153). Brochure, in this case, is leaflets containing pictures and information which is not only used to introduce a product or service but also to inform the public about a company or organization.

In general, the brochure serves as an informative medium, and aims to convey information so that the audience can increase their knowledge and insight. In addition, the brochure also aims to influence the public to change attitudes, opinions, behavior, or social change. (Iriantara \& Surachman, 2006: 162)

Brochure is usually intended for external public companies. The use of brochures by companies also functions as a corporate identity. In terms of the presence of the brochure made by the company, the brochure can show a good image for the company itself and build a trust to use the products or services offered by the company.

\section{METHODOLOGY}

The method used in this research was a qualitative method with a single case study design. A single case study has three rationalizations: first, when the case states an important case in testing a well-developed theory, both cases present an extreme or unique case and third is a disclosure case (Yin, 2011: 46). The uniqueness of the Health Education Process of Hospital Visitors Through this Educative Brochure, namely Siloam Hospitals Lippo Village, performs management consistently, even though digital media has developed rapidly.

Data on this qualitative research generally took the form of descriptions, narratives, data, images or statements obtained from research subjects, both directly and indirectly in campaign planning conducted by Siloam Hospitals Lippo Village. Lufland and Lofland (Moleong, 2013: 157). The main data sources in qualitative research are words and actions. Meanwhile, the rest are the additional data such as documents and others. In this regard, in this section the types of data are divided into words and actions, written data sources, photographs and statistics.

This research used purposive sampling technique. Purposive sampling is a sampling technique with certain considerations, for example, conducting research on food quality, the sample data source is a food expert. This sample is more suitable for qualitative research, or studies that do not make generalizations (Sugiyono, 2004: 124). One of the participants was Mr. Alexander Mutak as Head of Business Development of Siloam Hospitals Lippo Village who was responsible for all business activities at Siloam Hospitals Lippo Village, one of which was controlling the production of educational brochures, contributing topics in the educative brochure and agreeing on the feasibility of educational brochures. The second participant was Mas Slamet as Physician Relations in the Marketing division of Siloam Hospitals Lippo Village is responsible for the production of educational brochures, looking for topics for educational brochures and consulting topics in the educative brochure with the Infection Control Department 
at Siloam Hospitals Lippo Village. The third was Mrs. Mawati Sinurat as a visitor at Siloam Hospital Lippo Village's child policeman who was reading some of the educative brochures at Siloam Hospital Lippo Village. The fourth was Imas Nurhidayah as a visitor and an inpatient at Siloam Hospital Lippo Village.

The data collection techniques was interviews with the relevant participants and related to the Health Education Process of Hospital Visitors Through the Educative Brochure at Siloam Hospitals Lippo Village. In addition, the researcher also collected data through field observations. In addition, the researcher also collected data obtained from offices, books, (literature) or other parties who provide data that are closely related to the object and purpose of research (Tika, 2006: 64). The data taken was data that contains information value related to the Health Education Process of Hospital Visitors through the Educative Brochure at Siloam Hospitals Lippo Village, both from the website, books, documents, photos and so on.

\section{DISCUSSION}

Brochure is generally used by an organization or a company to explain brief, concise and clear information about a company. The brochure is also used to convey the company information and also as a promotion media for the company itself. At Siloam Hospital Lippo Village, the use of educational brochures in hospitals as a information media that can educate visitors. Siloam Hospital Lippo Village is well aware of its responsibility to heal the community and also educate the public about the diseases that are around the public.

Since the inception of Siloam Hospital Lippo Village in 1996, the hospital has been using educational brochure to educate visitors. Siloam Hospital Lippo Village does not only heal the public. However, they are also responsible for providing educative information so that the public is more alert to disease. Siloam Hospital Lippo Village is well aware of its responsibilities which furthermore established the communication with visitors by educating them using brochure media.

Based on the results of the study, the researcher found that what was done was in line with the concept of external organizational communication according to Khomsahrial Romli that an organization communicates to the organization's public using the media so that its public can feel involved with the organization. Siloam Hospital Lippo Village seeks to establish communication with its visitors by providing health education through educative brochures and later visitors will come back again to consult a doctor after reading the educative brochure.
The media brochure is used by Siloam Hospital Lippo Village as one of the media organizations used to convey information about disease prevention so that visitors can be educated and gain insight.

Based on the results of the study, the researcher found that the use of brochures at Siloam Hospital Lippo Village is in line with the concept of brochures according to Yosal and A. Yani namely brochure as informative media that aims to increase public knowledge and insight. In this case, when visitors read educational brochures that contain disease prevention measures such as how to wash hands consisting of 6 steps then good cough and sneezing ethics, visitors gain insight or new knowledge of what they usually apply in everyday life those who just wash their hands are simply exposed to water or sneeze and cough covering it with their hands.

Siloam Hospital Lippo Village uses brochures as information media in educating, because brochure media is considered as practical information media that can be carried anywhere. The educative information to be conveyed can be obtained practically and easily if placed in the educative brochure. The researcher sees that the brochure is easily obtained by visitors and can be directly read so that the educational process can be done easily.

The researcher found that the messages usually discussed in the brochure are simple things that can be an information related to prohibition and suggestion, such as the prevention of infection by diligently washing hands, ethics coughing and sneezing, diet tips for diabetes, pain management, and steps to wash hands. The messages contained in the Siloam Hospital Lippo Village brochure are in the form of educative information that can add visitors' insights so that visitors can re-apply them.

The value of the information contained in the educative brochure of Siloam Hospital Lippo Village is in line with the concept of the value of information according to Onong that information must contain informative and educative value. An information must be able to increase knowledge and introduce a new way to carry out activities for users or readers. Researcher sees that the visitors who have read, assess the information obtained after reading the brochure is considered very informative. The educative brochure that visitors read contained the simple infection prevention measures, but the impact of implementing effective prevention measures can be very beneficial for visitors.

Siloam Hospital Lippo Village visitors consist of various backgrounds, namely outpatients, inpatients, patient families, customers, medical and non-medical personnel. The Siloam Hospital Lippo Village educative brochure is intended for these visitors so that they are educated about infection prevention. 
Based on the results of the study, researcher found that the Siloam Hospital Lippo Village educative brochure was used by hospitals for branding purposes. When Siloam Hospital Lippo Village organized events both internally and externally, the brochures are distributed when the event runs so that visitors are educated about health while understanding the Siloam Hospital Lippo Village brand clearly. The educative brochure of Siloam Hospital Lippo Village was made with an attractive appearance to create a good brand image for the hospital.

Researcher also sees that the educative brochure used in hospitals can support the confidence of visitors to use the services offered in the Siloam Hospital Lippo Village educative brochure. Siloam Hospital Lippo Village will be trusted by visitors as a hospital that cares about the public because of the branding that is done through educative brochures.

The use of brochures as communication media is in line with Maria Assumpta's concept of the purpose of using media in Public Relations activities to increase public trust and enhance the good image for companies or organizations. Researcher found that this was done by Siloam Hospital Lippo Village to improve the good image of the hospital so that hospital visitors continue to entrust their health services to Siloam Hospital Lippo Village through an educative brochure distributed.

\section{CONCLUSION}

The Siloam Hospital Lippo Village educative brochure was beneficial both for visitors and Siloam Hospital Lippo Village. Visitors who come to the hospital and read the educative brochure of Siloam Hospital Lippo Village could receive the benefit from the brochure, for example, the public becomes aware of ways and preventive measures that can be taken to prevent illness both when visiting the hospital and when outside the hospital. . The visitors do not only receive health education information. However, by the educative brochure, visitors can see the seriousness and responsibility of the hospital to educate visitors through simple things. There is an increase trust when visitors read educative brochures produced by Siloam Hospital Lippo Village. In this case, the benefit of this media also is also felt by the Siloam Hospital Lippo Village, such as, Siloam Hospital Lippo Village can communicate health information to the extent of visitors and can reach all people in terms of education. Siloam Hospital Lippo Village also gets benefits through the educative brochures in terms of brand image. The educative brochure produced by Siloam Hospital Lippo Village can enhance a good brand image for hospitals.

\section{REFERENCES}

[1] Baum, Daniela; Spann, Martin; Fuller, Johann; Thurridl, Carina. The Impact Of Social Media Campaigns On The Success Of New Product Introductions. Journal of Retailing and Consumer Services. 0969-6989. Juli 2018.

[2] Libertine, Alodia Chandra. Strategi Kampanye "Breast Cancer Awareness Month". Jurnal E-Komunikasi. Universitas Kristen Petra, Surabaya. Vol 2. No.1 Tahun 2014

[3] Onong Uchjana Effendy. Ilmu, Teori dan Filsafat Komunikasi. Bandung: PT Citra Aditya Bakti. 2003

[4] Rumanti, Maria Assumpta. 2005. Dasar-Dasar Public Relations Teori dan Praktek. Jakarta: PT Grasindo

[5] Ruslan, Rosady. 2012. Manajemen Public Relations \& Media Komunikasi: Konsep dan Aplikasi. Jakarta: PT Raja Grafindo Persada.

[6] Sugiyono. 2005. Memahami Penelitian Kualitatif. Bandung: Alfabeta.

[7] Vercic, D., et al. Looking For Digital In Public Relations. Public Relations Review (2015), http://dx.doi.org/10.1016/j.pubrev.2014.12.002

[8] Wilcox L. Dennis, Ault H. Phillip, dan Agee K. Warren. 2006. Public Relations Strategi dan Taktis Jilid Satu. Penerjemah: Rosa Kristiwati. Interaksara.

[9] Yin, Robert K. 2011. Studi Kasus (Desain dan Mode). Jakarta: Raja Grasindo Perkasa.

[10] Yosal Iriantara \& A. Yani Surachman. Public Relations Writing: Pendekatan Teoretis dan Praktik. Simbiosa Rekatama Media. Bandung. 2006

[11] Yuliawati \& Irawan, Pera Enjang. Peran Cyber Public Relations Humas Polri Dalam Memberikan Pelayanan Informasi Publik Secara Online. Vol 1, No 1 (2016): Jurnal Politikom Indonesiana.

[12] Yuliawati. The Analysis of Campaign Media of the Green Environment Movement through the Hydroponics Program. American Journal of Humanities and Social Sciences Research (AJHSSR) Volume-2, Issue-12, 2018 pp-149-155

[13] Yuliawati. The Program Evaluation of the Green Environment Movement Campaign to Support the National Food Security (A Case Study of the Evaluation of Green Environment Program through Hydroponic Plants by Military District Command 0503 West Jakarta). International Journal of Humanities and Social Science Invention (IJHSSI). Volume 8 Issue 08 Ser. I Aug. 2019.

[14] http://hospitals.webometrics.info/en/Asia/Indonesia\%20 (diakses pada 13 Juni 2017 pukul 15.10). 